\title{
PENGARUH FAKTOR PSIKOLOGIS DALAM PEMILIHAN PROGRAM KEAHLIAN TEKNIK MESIN DI SEKOLAH MENENGAH KEJURUAN
}

\author{
Dwi Rahdiyanta \\ Pendidikan Teknik Mesin Fakultas Teknik Universitas Negeri Yogyakarta \\ dwi_rahdiyanta@uny.ac.id
}

\begin{abstract}
The purpose of the study was to determine the effect of psychological factors of students, composed of self-understanding, information literacy, and attitudes, to the choice of entering mechanical engineering study program in Vocational High Schools (VHSs) by Junior High School graduates. The research is a correlational ex post facto study. The population was 1064 students and the sample was 300 students which was sampled using proportional random sampling technique using the Krejcie and Morgan formula. The data were collected through inventories, observation sheets, and documents. The content validity was assessed through expert judgment. The construct validity was assessed using the factor analysis and the reliability using the Cronbach's Alpha formula. The data were analyzed using descriptive analysis, regression analysis, and path analysis at significance level of 0.05. The results show that: (1) There are positive and significant effects of information literacy, self-understanding and attitudes to the choice of mechanical engineering study program in VHSs; (2) Psychological factors, such as information literacy, self-understanding and attitudes, have significant effects, either directly or indirectly, to the choice of mechanical engineering study program in VHSs by Junior High Schools graduates.
\end{abstract}

Keywords: effect, psychological factor, mechanical engineering, vocational high school

\begin{abstract}
ABSTRAK
Tujuan penelitian ini adalah untuk mengetahui pengaruh faktor psikologis siswa yang terdiri dari aspek pemahaman diri, penguasaan informasi, dan sikap terhadap pemilihan program keahlian teknik mesin di SMK oleh para lulusan siswa SMP/MTs. Penelitian yang dilakukan merupakan penelitian korelasional dan bersifat expost facto. Populasi penelitian berjumlah 1064 orang siswa. Jumlah sampel penelitian sebanyak 300 siswa ditentukan dengan formula Krejcie dan Morgan. Pengambilan sampel dilakukan dengan teknik proportional random sampling. Data dikumpulkan dengan inventori, lembar pengamatan dan dokumentasi. Hasil penelitian menunjukkan bahwa: (1) Ada pengaruh yang positif dan signifikan penguasaan informasi, pemahaman diri, dan sikap siswa terhadap pemilihan program keahlian teknik mesin di SMK; (2) Faktor psikologis berupa penguasaan informasi, pemahaman diri dan sikap siswa memiliki pengaruh yang signifikan baik secara langsung maupun tidak langsung dalam menentukan pemilihan program keahlian teknik mesin di SMK bagi siswa lulusan SMP/MTs.
\end{abstract}

Kata kunci: pengaruh faktor psikologis, pilihan program keahlian di SMK

\section{PENDAHULUAN}

Sesuai dengan Undang-Undang Nomor 20 Tahun 2003 tentang Sistim Pendidikan Nasional, setelah siswa SMP/MTs lulus memiliki dua alternatif pilihan untuk melanjutkan pendidikan formal, yaitu pendidikan menengah umum dan pendidikan menengah kejuruan. Pendidikan menengah umum berbentuk Sekolah Menengah Atas (SMA) dan Madrasah Aliyah (MA), sedangkan pendidikan menengah kejuruan berbentuk Sekolah Menengah Kejuruan (SMK) dan Madrasah Aliyah Kejuruan (MAK). Sesuai dengan tujuannya, pendidikan SMA dan MA lebih mengutamakan penyiapan siswa untuk melanjutkan pendidikan pada jenjang pendidikan tinggi, sedangkan tujuan pendidikan SMK dan MAK lebih mengutamakan penyiapan siswa untuk memasuki lapangan kerja serta mengembangkan sikap profesional (Peraturan Menteri Pendidikan Nasional Nomor 22 Tahun 2006 Tentang Standar Isi). 
Dalam hal pilihan untuk melanjutkan pendidikannya ke SMK, para siswa kelas IX SMP/MTs perlu mendapatkan perhatian yang serius dari berbagai pihak agar dalam menentukan pilihan bidang keahlian yang ada di SMK mereka tidak keliru. Hal ini sangat beralasan mengingat begitu luasnya bidang keahlian yang ditawarkan di SMK sebagaimana yang telah ditetapkan dalam spektrum keahlian pendidikan menengah kejuruan. Spektrum keahlian pendidikan menengah kejuruan (SMK) dapat dikelompokkan menjadi 9 (sembilan) bidang studi keahlian, 46 program studi keahlian, dan 128 paket keahlian (Surat Keputusan Direktur Jenderal Pendidikan Menengah Nomor 7013/D/KP/2013 tanggal 4 Desember 2013 tentang Spektrum Keahlian Pendidikan Menengah Kejuruan).

Memikirkan jenis pendidikan atau latihan yang harus diikuti oleh seorang anak perlu mendapatkan perhatian, baik dari anak itu sendiri, dari orang tua maupun dari para guru. Hal ini penting guna menghindari adanya ketidakmantapan pada diri anak dalam memilih program-program pendidikan ataupun latihan lanjutan. Ketidakmantapan ini mungkin disebabkan oleh: 1) anak tidak mampu menentukan salah satu pilihan dari alternatif yang ada, 2) adanya kebimbangan karena tidak didukung oleh minat dan bakatnya, dan 3) adanya kebimbangan karena tidak memiliki rasa percaya diri (Crites, 1969: 25). Memilih jenis pendidikan atau latihan lanjutan yang tidak sesuai dengan minat akan mengakibatkan kegiatan belajar menjadi sesuatu yang tidak menyenangkan, sangat menyiksa, menegangkan dan penuh rasa keterpaksaan. Menurut Hurlock (1980: 221), siswa yang kurang berminat pada jenis pendidikan tertentu biasanya menunjukkan ketidaksenangan terhadap jenis pendidikan tersebut, yang berakibat pada pencapaian prestasi belajar yang rendah, bekerja di bawah kemampuannya dalam setiap mata pelajaran yang tidak disukainya, sering membolos sekolah, sampai berhenti sekolah sebelum waktunya.

Pilihan bidang keahlian pada hakekatnya adalah proses perpaduan antara kebutuhan- kebutuhan, harapan-harapan, sumber-sumber pribadi individu, dan tuntutan ekonomi (Super, 1957: 56; Vroom, 1979). Lebih lanjut London (1973: 74) mengemukakan bahwa pilihan bidang keahlian merupakan perpaduan antara minat, kemampuan, nilai-nilai, peluang, harapan dan adanya keterbatasan-keterbatasan dalam realita kehidupan. Untuk itulah perlu adanya informasi yang intensif dari sekolah kepada para siswa SMP/MTs terkait dengan pemilihan bidang keahlian di SMK. Hal ini mengingat bahwa informasi lengkap tentang deskripsi SMK baik yang meliputi visi, misi, dan tujuan SMK maupun jenis-jenis bidang keahlian yang diselenggarakan di SMK dirasakan masih sangat kurang dimengerti oleh para siswa kelas IX SMP (Sudji Munadi, 2005). Informasi tentang deskripsi SMK tersebut sangat membantu baik bagi guru maupun bagi siswa SMP dalam interaksi kegiatan belajar mengajar (Herrick, 2000).

Tiedeman \& O'Hara

mengemukakan bahwa pengambilan keputusan merupakan masalah yang pelik dalam tahapan perkembangan vokasional seseorang. Mereka mengemukakan bahwa ada hubungan antara kepribadian dan bidang kejuruan pada proses pilihan bidang kejuruan seseorang. Perkembangan kepribadian seseorang pada dasarnya merupakan proses mental seseorang sebagai konsekuensi keterlibatannya, baik dalam keberbedaaan maupun kebersamaan di masyarakat. Tiedeman menggunakan istilah identitas diri (ego identity) dalam mendeskripsikan kepribadian seseorang dalam kehidupan sosial kemasyarakatan. Identitas diri terbentuk karena adanya interaksi antara tiga faktor yaitu: kondisi biologis individu, psikologis dan sosial atau budaya tempat individu berada. Oleh karena itu, keputusan vokasional yang diambil oleh individu selalu mempertimbangkan adanya benturan antara pola kehidupan dan struktur pengembangan vokasional.

Berdasarkan pendapat Isaacson (1977: 46) bahwa dalam proses pemilihan karir atau keahlian terdapat empat variabel yang 
mempengaruhinya, yaitu: reality factors, educational process, emotional factors, dan personal values. Reality factors menyangkut respon seseorang terhadap kondisi lingkungan di sekitarnya yang memaksa diri orang tersebut untuk membuat keputusan berkaitan dengan karirnya. Educational process berkaitan dengan kualitas dan kuantitas pendidikan yang diperoleh seseorang yang memungkinkan membuka wawasan orang tersebut untuk menentukan pilihan karir. Emotional factors adalah hal-hal yang menyangkut aspek-aspek kepribadian. Personal values adalah aspek-aspek nilai yang melekat pada diri seseorang yang ikut mempengaruhi dalam memilih karir.

Pemilihan bidang keahlian merupakan psychological individual awareness of the objective world in its relation to the self (Moris, 1982: 355). Lebih lanjut disebutkan bahwa perkembangan vokasional seseorang hakekatnya merupakan interaksi antara perilaku, sikap, ambisi dan nilai-nilai individu dengan faktorfaktor sosial di sekitarnya (Super, 1957: 56). Jadi, pemilihan bidang keahlian merupakan proses psikologi dari diri seseorang untuk menentukan sikap yang tepat dan benar dalam menghadapi sesuatu obyek.

Karakter atau kepribadian seseorang akan mempengaruhi orang tersebut dalam menyikapi adanya berbagai ragam keahlian atau pekerjaan yang ada di masyarakat (Holland, 1973: 88). Hal ini berarti bahwa setiap orang akan memilih karir atau pekerjaan tertentu sesuai dengan karakternya masing-masing. Berdasarkan teori Holland tersebut orang akan melihat kedalam dirinya sendiri (pemahaman diri) untuk mengukur cocok tidaknya suatu karir atau pekerjaan dengan dirinya. Hal ini berarti pemahaman diri (self knowledge) merupakan salah satu faktor penting yang berpengaruh dalam pemilihan bidang kejuruan. Sedangkan menurut Victor Vroom (1979), bahwa seseorang akan memilih suatu bidang kejuruan atau pekerjaan tertentu jika mereka memiliki keyakinan dan harapan bahwa pekerjaan atau bidang keahlian yang dipilihnya akan membawa keberhasilan maka ia akan berusaha dengan sekuat tenaga untuk mendapatkan bidang keahlian atau pekerjaan tersebut.

Permasalahan yang terkait dengan aspek psikologi/individu siswa adalah: (1) lulusan siswa SMP/MTs belum sepenuhnya mengetahui berbagai bidang keahlian yang ditawarkan di SMK, (2) lulusan siswa SMP/MTs belum memiliki pemahaman tentang dunia kerja yang terkait dengan bidang keahlian yang ditawarkan di SMK, (3) lulusan siswa SMP/MTs belum mengetahui persyaratan yang harus dipenuhi baik yang terkait dengan aspek kognitif maupun pisik pada masing-masing program keahlian yang ada di SMK, (4) sebagian besar siswa SMP/MTs belum menguasai teknologi informasi sehingga mereka kurang dapat mengikuti perkembangan teknologi dan keduniakerjaan yang sangat penting kaitannya dengan ketepatan dalam pemilihan bidang keahlian di SMK, hal ini dikarenakan masih kurangnya fasilitas pendukung baik berupa media cetak maupun elektronik pada sebagian besar SMP/MTs, dan (5) lulusan siswa SMP/MTs belum sepenuhnya memiliki pemahaman diri yang baik terkait dengan ketepatan dalam pemilihan bidang keahlian yang ada di SMK.

Spektrum keahlian di SMK cukup luas, maka penelitian ini difokuskan pada pemilihan program keahlian teknik mesin di SMK. Adapun faktor-faktor determinan dalam pemilihan bidang keahlian teknik mesin di SMK dibatasi pada faktor psikologis siswa yang terdiri dari aspek penguasaan informasi, pemahaman diri, dan sikap siswa terhadap program keahlian teknik mesin SMK.

Tujuan penelitian ini adalah: (1) untuk mengetahui gambaran faktor psikologis siswa yang meliputi aspek pemahaman diri, penguasaan informasi, sikap, dan pilihan program keahlian teknik mesin di SMK oleh para lulusan siswa SMP/MTs di Daerah Istimewa Yogyakarta, dan (2) untuk mengetahui pengaruh faktor psikologis siswa yang terdiri dari aspek pemahaman diri, penguasaan informasi, dan sikap terhadap pemilihan program keahlian teknik mesin di SMK oleh para lulusan 
siswa SMP/MTs di Daerah Istimewa Yogyakarta.

\section{METODE}

Penelitian ini merupakan penelitian korelasional, bertujuan untuk merumuskan faktor-faktor yang berpengaruh terhadap pemilihan program keahlian teknik mesin di SMK oleh para lulusan siswa SMP/MTs di DIY.

Populasi dalam penelitian ini adalah adalah lulusan siswa SMP/MTs yang baru saja masuk di SMK pada kelas $\mathrm{X}$ Kelompok Keahlian Teknologi dan Industri, Program Keahlian Teknik Mesin di Daerah Istimewa Yogyakarta yang berjumlah 1064 orang siswa. Jumlah sampel ditentukan dengan mendasarkan pada penentuan ukuran sampel menurut Krejcie dan Morgan (Issac, 1981: 192) menggunakan taraf kesalahan 5\%. Berdasarkan hasil perhitungan, diperoleh ukuran sampel sebesar 278 responden (pembulatan). Untuk mengantisipasi angket maupun data yang tidak dapat terolah, jumlah sampel ditambah sebesar 5\%. Dengan demikian sampel minimal yang digunakan dalam penelitian ini adalah sebesar: $278+(5 \% \times 278)=$ 292 responden (pembulatan). Teknik sampling yang digunakan adalah proportional random sampling sehingga jumlah sampel kelompok dihitung berdasarkan jumlah populasi masingmasing kelompok.

Teknik pengumpulan data dalam penelitian ini adalah survey dengan menggunakan alat pengumpul data berupa angket, lembar pengamatan, dan dokumentasi. Validitas instrumen dalam penelitian ini meliputi validitas isi (content validity) dan validitas konstruk (construct validity). Untuk mengetahui validitas isi instrumen dilakukan melalui expert judgement dengan teknik Delphi. Pengujian validitas konstruk menggunakan analisis faktor konfirmatori untuk mengetahui apakah butirbutir instrumen tersebut cocok untuk menaksir unsur-unsur yang terdapat dalam konstruk yang telah ditetapkan (Ary, Jacobs Razavieh, 1982:289-291; Coakes \& Stead, 1996:123). Perhitungan reliabilitas instrumen penelitian menggunakan kaidah Cronbach Alpha (Fernandes, 1984:61). Hasil uji reliabilitas istrumen untuk penguasaan informasi sebesar 0,88 ; pemahaman diri sebesar 0,79 ; sikap siswa sebesar 0,91; dan pilihan bidang keahlian teknik mesin SMK sebesar 0,93. Dengan demikian berarti instrumen penelitian yang telah disisin dapat digunakan untuk pengumpulan data penelitian.

Teknik analisis data dalam penelitian ini meliputi dua analisis yaitu analisis deskriptif dan analisis inferensial (uji hipotesis) yang meliputi analisis korelasi, regresi dan analisis jalur, dengan terlebih dahulu dilakukan uji persyaratan analisis (normalitas, linieritas, homoskedastisitas, dan multikolinieritas). Tata hubung antar variabel dalam penelitian ini ditampilkan pada Gambar 1 berikut ini.

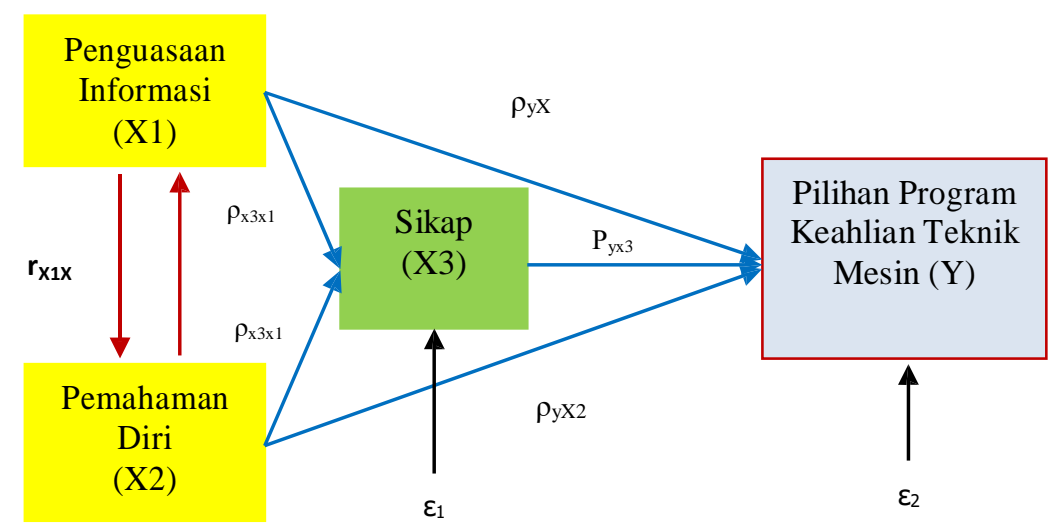

Gambar 1. Tatahubung Antar Variabel 


\section{HASIL DAN PEMBAHASAN}

Deskripsi data dalam penelitian ini meliputi penyajian ukuran distribusi frekuensi, ukuran tendensi sentral (mean, modus, median), ukuran penyebaran (simpangan baku), dan interpretasi deskriptif dari variabel penguasaan informasi (X1), pemahaman diri (X2), sikap siswa (X3), dan pemilihan program keahlian teknik mesin di SMK (Y). Rangkuman hasil analisis disajikan dalam Tabel 1 berikut:

Tabel 1. Ringkasan Hasil Analisis Deskriptif

\begin{tabular}{ccccccccc}
\hline Var. & SD. & Mi & M & Me & Mo & M : Mi & Pencapaian Skor (\%) & Kategori \\
\hline X1 & 9,67 & 78 & 95,66 & 95,00 & 96,00 & Lebih besar & 73,5 & Tinggi \\
X2 & 5,41 & 33 & 44,03 & 44,00 & 44,00 & Lebih besar & 80,3 & Tinggi \\
X3 & 7,16 & 54 & 75,29 & 75,00 & 72,00 & Lebih besar & 83,6 & Tinggi \\
Y & 6,92 & 51 & 69,22 & 69,00 & 70,00 & Lebih besar & 81,0 & Tinggi \\
\hline
\end{tabular}

Berdasarkan hasil analisis deskriptif dapat diketahui bahwa skor rata-rata empiris (M) > skor rata-rata kriteria (Mi). Tabel 1 tersebut juga dapat diketahui bahwa pencapaian skor untuk semua variabel penelitian di atas 70 $\%$, dengan demikian dapat disimpulkan bahwa seluruh variabel dalam penelitian ini secara umum termasuk dalam kategori tinggi.

Korelasi atau hubungan antar masingmasing variabel penelitian dapat diketahui dengan menguji hipotesis: Ada hubungan yang signifikan antar masing-masing variabel penelitian yaitu: penguasaan informasi $\left(\mathrm{X}_{1}\right)$, pemahaman diri $\left(\mathrm{X}_{2}\right)$, sikap siswa $\left(\mathrm{X}_{3}\right)$, dan pilihan program keahlian teknik mesin di SMK (Y). Untuk menguji hipotesis ini digunakan analisis korelasi jenjang nihil antara masingmasing variabel penelitian dengan product moment dari Pearson. Berdasarkan hasil analisis korelasi antar masing-masing variabel penelitian sebagaimana dapat dilihat pada Tabel 2, dapat disimpulkan bahwa hipotesis yang menyatakan terdapat hubungan yang positif dan signifikan antara masing-masing variabel penelitian diterima dan teruji kebenarannya pada taraf signifikansi 0,05. Rangkuman hasil analisis korelasi antar masing-masing variabel penelitian tersaji pada Tabel 2 berikut ini.

Tabel 2. Rangkuman Analisis Korelasi Jenjang Nihil Antar Variabel Penelitian

\begin{tabular}{llrrrr}
\hline & & \multicolumn{1}{c}{ X1 } & \multicolumn{1}{c}{ X2 } & \multicolumn{1}{c}{ X3 } & \multicolumn{1}{c}{ Y } \\
\hline \multirow{2}{*}{ X1 } & Pearson Correlation & 1 & .582 & .448 & .545 \\
& Sig. & .000 & .000 & .000 & .000 \\
X2 & Pearson Correlation & .582 & 1 & .535 & .515 \\
& Sig. & .000 & .000 & .000 & .000 \\
X3 & Pearson Correlation & .448 & .535 & 1 & .651 \\
& Sig. & .000 & .000 & .000 & .000 \\
& Pearson Correlation & .545 & .515 & .651 & 1 \\
& Sig. & .000 & .000 & .000 & .000 \\
\hline
\end{tabular}

Pengaruh penguasaan informasi, dan pemahaman diri siswa terhadap sikap siswa dapat diketahui dengan menguji hipotesis: Ada pengaruh signifikan penguasaan informasi $\left(\mathrm{X}_{1}\right)$, dan pemahaman diri siswa $\left(\mathrm{X}_{2}\right)$ terhadap sikap siswa pada SMK $\left(\mathrm{X}_{3}\right)$. Untuk menguji hipotesis ini digunakan analisis regresi ganda dengan menempatkan $\mathrm{X}_{3}$ sebagai variabel terikat dan $\mathrm{X}_{1}$ dan $\mathrm{X}_{2}$ sebagai variabel bebas. Rangkuman hasil analisis tersaji dalam Tabel 3 berikut ini. 
Tabel 3. Rangkuman hasil Analisis Regresi Ganda Variabel $\mathrm{X}_{3}$ atas Variabel $\mathrm{X}_{1}$, dan $\mathrm{X}_{2}$.

\begin{tabular}{|c|c|c|c|c|c|c|c|}
\hline \multicolumn{2}{|c|}{ Variabel } & \multirow{2}{*}{ B } & \multirow{2}{*}{ Beta } & \multirow{2}{*}{$\mathrm{r}_{\mathrm{par}}$} & \multirow{2}{*}{$\begin{array}{c}\text { Det. } \\
\text { Parsial } \\
\left(\mathrm{r}_{\text {par }}^{2}\right)\end{array}$} & \multirow{2}{*}{$t_{\text {hitung }}$} & \multirow{2}{*}{ Sig. $\mathrm{t}$} \\
\hline Terikat & Bebas & & & & & & \\
\hline $\mathrm{X} 3$ & $\mathrm{X} 1$ & 0,225 & 0,305 & 0.267 & 0.071 & 4,743 & 0,000 \\
\hline $\begin{array}{l}R=0,695 \\
R^{2}=0,483 \\
F=55,000 \\
P<0,05 \\
C=25,13\end{array}$ & $\mathrm{X} 2$ & 0,572 & 0,433 & 0.423 & 0.179 & 4,994 & 0,000 \\
\hline
\end{tabular}

Hasil analisis regresi ganda berdasarkan Tabel 3 di atas menunjukkan bahwa $\mathrm{F}_{\text {hitung }}=$ 55,00 dan $\mathrm{p}<0.05$; dengan demikian berarti harga korelasi $(\mathrm{R})=0,695$ adalah signifikan pada taraf signifikansi 0,05 . Berdasarkan hasil analisis tersebut maka hipotesis yang menyatakan: Ada pengaruh signifikan penguasaan informasi $\left(\mathrm{X}_{1}\right)$, dan pemahaman diri siswa $\left(\mathrm{X}_{2}\right)$ terhadap sikap siswa pada $\mathrm{SMK}\left(\mathrm{X}_{3}\right)$ diterima. Koefisien determinasi $\left(\mathrm{R}^{2}\right)=0,483$ menunjukkan sumbangan dua variabel tersebut sebesar $48,3 \%$.
Hipotesis yang diuji adalah ada pengaruh signifikan penguasaan informasi $\left(\mathrm{X}_{1}\right)$, pemahaman diri siswa $\left(\mathrm{X}_{2}\right)$, dan sikap siswa $\left(\mathrm{X}_{3}\right)$ terhadap pemilihan program keahlian teknik mesin di SMK (Y). Untuk menguji hipotesis ini digunakan analisis regresi ganda dengan menempatkan $\mathrm{Y}$ sebagai variabel terikat dan $\mathrm{X}_{1}$, $\mathrm{X}_{2}$, dan $\mathrm{X}_{3}$ sebagai variabel bebas. Rangkuman hasil analisis regresi ganda tersaji pada Tabel 4 berikut ini.

Tabel 4. Rangkuman hasil Analisis Regresi Ganda Variabel $\mathrm{Y}$ atas Variabel $\mathrm{X}_{1}, \mathrm{X}_{2}$, dan $\mathrm{X}_{3}$

\begin{tabular}{|c|c|c|c|c|c|c|c|}
\hline \multicolumn{2}{|c|}{ Variabel } & \multirow{2}{*}{ B } & \multirow{2}{*}{ Beta } & \multirow{2}{*}{$\mathrm{r}_{\mathrm{par}}$} & \multirow{2}{*}{$\begin{array}{c}\text { Det. } \\
\text { Parsial } \\
\left(\mathrm{r}^{2}{ }_{\text {par }}\right)\end{array}$} & \multirow{2}{*}{$t_{\text {hitung }}$} & \multirow{2}{*}{ Sig. $t$} \\
\hline Terikat & Bebas & & & & & & \\
\hline Y & $X_{1}$ & 0,019 & 0,057 & 0.075 & 0.006 & 0,722 & 0,026 \\
\hline $\begin{array}{l}R=0,733 \\
R^{2}=0,538 \\
F=56,816\end{array}$ & $X_{2}$ & 0,284 & 0,222 & 0.223 & 0.050 & 3,992 & 0,000 \\
\hline $\begin{array}{l}\mathrm{P}<0,05 \\
\mathrm{C}=12,199\end{array}$ & $X_{3}$ & 0,366 & 0,378 & 0.371 & 0.138 & 6,844 & 0,000 \\
\hline
\end{tabular}

Hasil analisis regresi ganda berdasarkan tabel 4 di atas menunjukkan bahwa $F_{\text {hitung }}=$ 56,815) dan $\mathrm{p}<0,05$; dengan demikian berarti harga korelasi $(\mathrm{R})=0,538$ adalah signifikan pada taraf signifikansi 0,05 . Berdasarkan hasil analisis tersebut maka hipotesis yang menyatakan: Ada pengaruh signifikan penguasaan informasi $\left(\mathrm{X}_{1}\right)$, pemahaman diri siswa $\left(\mathrm{X}_{2}\right)$, dan sikap siswa pada SMK $\left(\mathrm{X}_{3}\right)$ terhadap pemilihan program keahlian teknik mesin di SMK (Y): diterima. Koefisien determinasi $\left(\mathrm{R}^{2}\right)=0,538$ menunjukkan sumbangan tiga variabel tersebut sebesar $53,8 \%$.

Secara sendiri-sendiri penguasaan informasi $\left(X_{1}\right)$ memiliki pengaruh yang signifikan terhadap pemilihan program keahlian teknik mesin di SMK $(\beta=0,057: p>0,05)$, pemahaman diri siswa $\left(\mathrm{X}_{5}\right)$ memiliki pengaruh signifikan terhadap pemilihan program keahlian teknik mesin di SMK $(\beta=0,222: p<0,05)$, dan sikap siswa pada SMK (X6) memiliki pengaruh signifikan terhadap pemilihan program keahlian teknik mesin di SMK $(\beta=0,378: p<0,05)$. Berdasarkan 
koefisien determinasi parsialnya, sikap siswa mempunyai sumbangan terbesar terhadap pemilihan program keahlian teknik mesin di SMK (13,8\%), pemahaman diri (5\%), dan penguasaan informasi $(0,6 \%)$. Dengan demikian sikap siswa memiliki pengaruh yang lebih dominan dalam menentukan pemilihan program keahlian teknik mesin di SMK.

Berdasarkan harga prediktor dan konstanta hasil regresi ganda, dapat disusun persamaan regresi ganda sebagai berikut: $\mathrm{Y}=12,199+$
$0,019 X_{1}+0,284 X_{2}+0,366 X_{3}$. Dari hasil persamaan regresi tersebut dapat diketahui bahwa rata-rata skor pemilihan program keahlian teknik mesin di SMK akan meningkat atau menurun masing-masing sebesar $(0,019),(0,284)$ dan $(0,366)$ untuk kenaikan/penurunan penguasaan informasi, pemahaman diri, dan sikap siswa pada SMK sebesar satu unit.

Model hubungan kausal empirik yang memuat bobot regresi $(\beta)$ atau koefisien jalur disajikan pada Gambar 2.

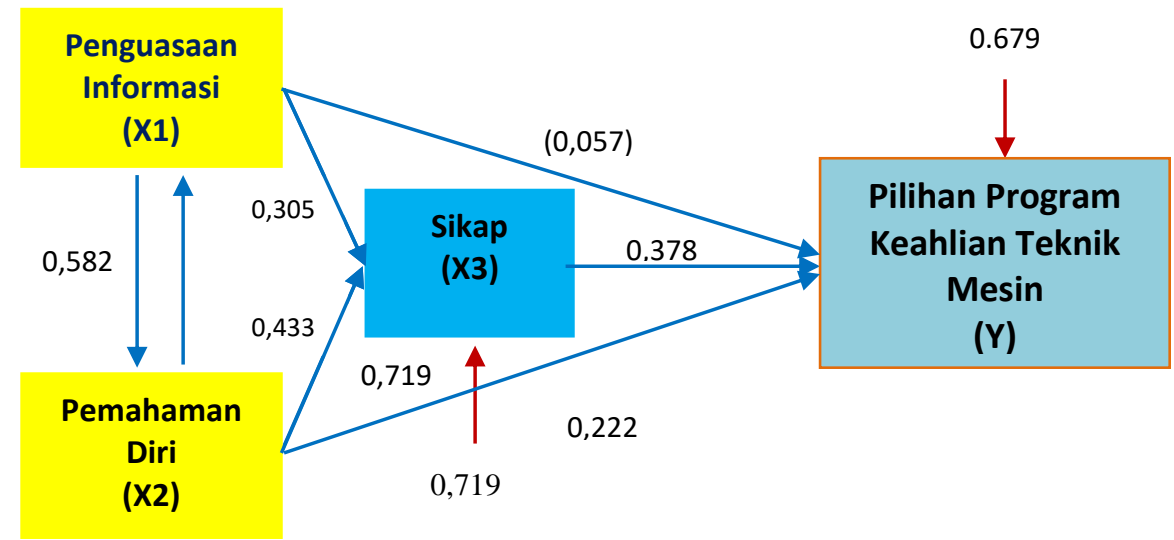

Gambar 2. Model Hubungan Kausal Empirik

Analisis Jalur untuk menguji pengaruh langsung dan tidak langsung dilakukan dengan menguji signifikansi koefisien jalur berdasarkan model hubungan kausal empirik. Harga koefisien jalur di bawah 0,05 dinyatakan tidak signifikan dan dikeluarkan dari model hubungan kausal empirik. Besarnya pengaruh langsung dapat diketahui dari koefisien beta hasil dua analisis regresi dengan menggunakan metode stepwise yaitu: (1) regresi ganda variabel $\mathrm{X}_{3}$ atas variabel
$\mathrm{X}_{1}$, dan $\mathrm{X}_{2}$, dan (2) regresi ganda variabel $\mathrm{Y}$ atas variabel $\mathrm{X}_{1}, \mathrm{X}_{2}$, dan $\mathrm{X}_{3}$. Sedangkan pengaruh tidak langsung dihitung secara manual berdasarkan besarnya koefisien jalur langsung sesuai model hubungan kausal.

Adapun rangkuman hasil perhitungan besarnya pengaruh langsung, pengaruh tidak langsung, pengaruh non kausal dari model hubungan kausal tersebut dapat dilihat pada Tabel 5 berikut ini.

Tabel 5. Rangkuman Hasil Analisis Jalur

\begin{tabular}{|c|c|c|c|c|c|c|}
\hline \multicolumn{2}{|c|}{ Variabel } & \multirow{2}{*}{$\begin{array}{c}\text { Efek } \\
\text { Langsung }\end{array}$} & \multirow{2}{*}{$\begin{array}{c}\text { Efek tak Langsung } \\
\text { Melalui } \\
\mathrm{X}_{3} \\
\end{array}$} & \multirow{2}{*}{$\begin{array}{l}\text { Efek } \\
\text { Total }\end{array}$} & \multirow{2}{*}{$\begin{array}{l}\text { Efek Non- } \\
\text { Kausal }\end{array}$} & \multirow{2}{*}{ Korelasi } \\
\hline Terikat & Bebas & & & & & \\
\hline \multirow{2}{*}{$\mathrm{X} 3$} & $\mathrm{X}_{1}$ & 0,305 & - & 0,305 & 0.124 & 0,448 \\
\hline & $\mathrm{X}_{2}$ & 0,433 & - & 0,433 & 0.206 & 0,535 \\
\hline \multirow{3}{*}{ Y } & $\mathrm{X}_{1}$ & 0,057 & 0,040 & 0,040 & 0.234 & 0,545 \\
\hline & $\mathrm{X}_{2}$ & 0,225 & 0,162 & 0,162 & 0.210 & 0,515 \\
\hline & $\mathrm{X}_{3}$ & 0,378 & - & 0,378 & 0.409 & 0,651 \\
\hline
\end{tabular}


Berdasarkan perhitungan besarnya pengaruh langsung dan tidak langsung dapat diketahui: (a) pengaruh langsung penguasaan informasi terhadap pemilihan program keahlian teknik mesin di SMK signifikan, demikian juga pengaruh tidak langsung melalui sikap siswa signifikan, (b) pengaruh langsung pemahaman diri siswa terhadap pemilihan program keahlian di SMK signifikan. Demikian juga pengaruh tidak langsung melalui sikap siswa signifikan.

Berdasarkan hasil analisis jalur tersebut dapat disimpulkan bahwa penguasaan informasi siswa, pemahaman diri siswa, dan sikap siswa memiliki peran yang sangat penting dalam pemilihan program keahlian teknik mesin di SMK.

Berdasarkan hasil analisis korelasi antar variabel penelitian, dapat diketahui bahwa hubungan antar variabel termasuk dalam kriteria cukup kuat. Adapun angka korelasi yang paling kecil terdapat pada hubungan antara penguasaan informasi dengan sikap siswa $(\mathrm{r}=0,448)$. Sedangkan angka korelasi yang paling besar terdapat pada hubungan antara sikap siswa dengan pilihan bidang keahlian teknik mesin di SMK ( $\mathrm{r}=0,651)$. Adanya korelasi yang kuat antara sikap siswa dengan pemilihan bidang keahlian teknik mesin di SMK, mengindikasikan bahwa sikap siswa memiliki pengaruh yang kuat terhadap pemilihan bidang keahlian teknik mesin di SMK. Hal ini sesuai dengan hasil penelitian Paul (2008) dan Cris Zirkle (2005), yang menemukan bahwa terdapat hubungan yang positif antara sikap dan motivasi dengan keberhasilan dalam pemilihan bidang keahlian. Oleh sebab itu maka sikap siswa terhadap SMK perlu dipertahankan dan ditingkatkan lagi dengan cara meningkatkan kualitas proses, output dan out-come di SMK, sehingga citra SMK di masyarakat akan lebih baik lagi.

Berdasarkan hasil analisis regresi ganda menunjukkan bahwa penguasaan informasi, pemahaman diri dan sikap siswa pada SMK memiliki pengaruh yang positif dan signifikan terhadap pemilihan program keahlian teknik mesin di SMK. Demikian juga ternyata secara sendiri-sendiri penguasaan informasi, pemahaman diri dan sikap siswa pada SMK memiliki pengaruh yang signifikan terhadap pemilihan program keahlian teknik mesin di SMK. Dengan adanya pengaruh yang signifikan penguasaan informasi terhadap pemilihan bidang keahlian di SMK, maka hasil temuan ini juga selaras dengan hasil penelitian Hendley \& Tanner (1996), yang menemukan bahwa penguasaan informasi tentang ilmu pengetahuan dan teknologi banyak memberikan pengaruh terhadap orientasi pilihan bidang keahlian seseorang.

Hasil penelitian ini juga selaras dengan penelitian Ahmad Zahrowi (2007), yang menemukan bahwa penguasaan informasi tentang lapangan kerja memberikan sumbangan sebesar 74,4\% terhadap minat siswa kelas 3 (tiga) SMP untuk memilih SMK. Temuan tersebut di atas juga selaras dengan berbagai rumusan (Sumitro, dkk., 1998: 80; Syamsu Yusuf, 2001: 75; Ary Gunawan, 2010: 21; dan Mohammad Ali:141), yang menyatakan bahwa faktor penguasaan informasi, pemahaman diri dan sikap siswa merupakan faktor yang berpengaruh dan menentukan ketepatan dalam pemilihan bidang keahlian di SMK. Kurangnya wawasan lulusan SMP terhadap dunia kerja juga dapat mempengaruhi dalam pemilihan sekolah lanjutan (Hurlock, 1980:166).

Hasil penelitian ini juga selaras dengan hasil penelitian yang menyatakan bahwa pemahaman diri para lulusan siswa SMP masih sangat kurang, sehingga akan berakibat pada persepsi dan sikap siswa pada SMK yang kurang baik yang pada gilirannnya akan sangat berpengaruh terhadap keakuratan dalam penentuan bidang keahlian di SMK (Ahmad Zahrowi (2007).

Hasil analisis jalur menunjukkan bahwa pengaruh langsung penguasaan informasi terhadap pemilihan bidang keahlian teknik mesin di SMK signifikan, demikian juga pengaruh tidak langsung melalui sikap signifikan. Hasil analisis jalur tersebut menunjukkan bahwa sikap siswa mempunyai arti dalam menjelaskan pengaruh penguasaan informasi terhadap pemilihan bidang keahlian di SMK. Hasil ini selaras dengan hasil penelitian yang menyatakan 
bahwa penguasaan informasi para lulusan siswa SMP tentang SMK akan sangat berpengaruh pada persepsi dan sikap pada SMK yang yang pada gilirannnya akan sangat berpengaruh terhadap keakuratan dalam penentuan bidang keahlian di SMK (Ahmad Zahrowi, 2007; dan Hurlock, 1980:166). Dengan demikian berarti bahwa penguasan informasi merupakan salah faktor yang amat bermanfaat dalam pengambilan suatu keputusan. Jika dikaitkan dengan pemilihan bidang kejuruan di SMK oleh lulusan siswa SMP/MTs, maka siswa yang memiliki penguasaan informasi yang baik tentu akan lebih memiliki pertimbangan-pertimbangan yang lebih baik dan akurat dalam memilih bidang kejuruan di SMK. Penguasaan informasi juga sangat dipengaruhi oleh faktor situasional baik dari aspek lingkungan sekolah, lingkungan keluarga dan lingkungan sosial masyarakat. Hal ini berarti jika faktor situasional tersebut baik, maka akan mendukung terjadinya proses penguasaan informasi yang baik pula yang pada gilirannya akan memberikan pada anak wawasan yang yang berkaitan dengan citra SMK, perkembangan ilmu pengetahuan dan teknologi, serta dunia kerja khususnya yang terkait dengan bidang keahlian teknik mesin.

Hasil analisis jalur juga menunjukkan bahwa pengaruh langsung pemahaman diri terhadap pemilihan bidang keahlian teknik mesin di SMK signifikan, demikian juga pengaruh tidak langsung melalui sikap signifikan. Hasil analisis jalur tersebut menunjukkan bahwa sikap siswa mempunyai arti dalam menjelaskan pengaruh pemahaman diri terhadap pemilihan bidang keahlian di SMK. Hasil temuan ini selaras dengan pendapat Mifflen dan Mifflen (1986: 65) yang menyatakan bahwa konsep diri atau pemahaman diri memegang peran yang sangat dominan dalam pembentukan kepribafian dan sikap anak. Dengan demikian berarti bahwa kemampuan memahami diri sendiri merupakan satu aktivitas psikologis yang penting dalam diri individu untuk melakukan sesuatu. Seseorang yang memahami dengan baik akan potensi diri yang dimiliki maka hal ini akan berpengaruh terhadap orientasi pilihan pada bidang kejuruan atau pekerjaan yang diidamkan oleh siswa. Hal ini sangat beralasan mengingat bahwa setiap bidang keahlian atau pekerjaan tentu memiliki karakteristik dan persyaratan yang diperlukan, serta akan memiliki dampak intrinsik dan ekstrinsik bila memiliki pekerjaan tersebut.

Hasil analisis jalur juga menunjukkan bahwa sikap siswa terhadap SMK memiliki pengaruh yang signifikan dan paling besar terhadap pemilihan program keahlian di SMK oleh para lulusan SMP/MTs. Hal ini selaras dengan pendapat Mohammad Ali dan Mohammad Asrori (2009:141), bahwa sikap merupakan salah satu aspek psikologis individu yang sangat penting, karena sikap merupakan kecenderungan seseorang untuk berperilaku sehingga akan banyak mewarnai perilaku seseorang. Sikap merupakan kecenderungan untuk bereaksi terhadap orang, lembaga, atau peristiwa baik secara positif mapun negatif. Lebih lanjut disebutkan bahwa menurut teori determinisme, sikap manusia diturunkan atau dipengaruhi oleh determinisme genetis (genetic determinism), determinisme psikis (psychic determinism), dan determinisme lingkungan (environmental deteriminism). Determinisme genetis memiliki pandangan bahwa sikap individu diturunkan oleh sikap kakek-neneknya. Determinisme psikis berpandangan bahwa sikap individu merupakan hasil dari perlakuan, pola asuh, atau pendidikan orang tua yang diberikan kepada anaknya. Determinisme lingkungan (environmental determism) berpandangan bahwa perkembangan sikap seseorang sangat dipengaruhi oleh lingkungan tempat individu tinggal dan bagaimana lingkungan memperlakukan individu tersebut. Demikian juga menurut Thompson (1973), bahwa pemilihan bidang kejuruan seseorang dipengaruhi oleh aspek sosial dan psikologis. Dari uraian di atas dapat disimpulkan bahwa sikap seseorang disamping dipengaruhi faktor dari dalam yaitu pemahaman terhadap dirinya dan penguasaan informasi, juga dipengaruhi oleh faktor dari luar yaitu lingkungan orang tua, lingkungan sekolah, dan lingkungan sosial masyarakat dimana mereka tinggal. 


\section{SIMPULAN}

Hasil pengujian hipotesis diperoleh simpulan: (1) terdapat hubungan yang positif dan signifikan antara masing-masing variabel penguasaan informasi, pemahaman diri, sikap siswa, dan pilihan program keahlian teknik mesin di SMK. Hubungan antar variabel dalam penelitian ini termasuk dalam kriteria kuat. Adapun angka korelasi yang paling kecil terdapat pada hubungan antara lingkungan keluarga dengan sikap siswa $(\mathrm{r}=0,448)$. Sedangkan angka korelasi yang paling besar terdapat pada hubungan antara sikap siswa dengan pilihan bidang keahlian teknik mesin di SMK $(r=0,651)$, (2) penguasaan informasi, pemahaman diri, dan sikap siswa memiliki pengaruh yang positif dan signifikan terhadap pemilihan program keahlian teknik mesin di SMK dengan sumbangan sebesar 53,8\%. Berdasarkan koefisien determinasi parsialnya, sikap siswa mempunyai sumbangan terbesar terhadap pemilihan bidang keahlian teknik mesin di SMK (13,8\%), diikuti secara berurutan pemahaman diri (5\%), dan penguasaan informasi $(4,6 \%)$. Dengan demikian sikap siswa memiliki pengaruh yang lebih dominan dalam menentukan pilihan program keahlian teknik mesin di SMK, (3) faktor psikologis berupa penguasaan informasi, pemahaman diri dan sikap siswa memiliki pengaruh yang positif dan signifikan baik secara langsung maupun tidak langsung dalam menentukan pemilihan program keahlian teknik mesin di SMK bagi siswa lulusan SMP/MTs.

Penguasaan informasi, pemahaman diri dan sikap siswa memiliki peran penting dalam menentukan pemilihan program keahlian teknik mesin di SMK. Oleh karenanya para siswa SMP/MTs perlu selalu didorong untuk dapat meningkatkan kapasitas diri khususnya yang terkait dengan kemampuan penguasaan informasi, pemahaman diri dan pengembangan sikap dengan penyediaan berbagai akses media informasi dan pemberian bimbingan kejuruan yang lebih intensif lagi.

\section{DAFTAR RUJUKAN}

Ary, Donald., Jacobs \& Razavieh. (1982). Introduction to research in education. New York: Holt, Rinehart and Winston.

Coakes, S.J., \& Steed, L.G. (1996). SPSS for Windows: Analysis without anguish. New York: John Wiley \& Sons.

Cris Zirkle. (2005). Distance education programming barriers in career and technical education in Ohio. The Journal of Vocation Educational Research. Vol. 29, pp. 157-179.

Crites, J.O. (1969). Vocational psychology. The study of vocational behavior and development. New York: McGraw-Hill Book Company.

Depdiknas, (2006). Peraturan Menteri Pendidikan Nasional Nomor 22 Tahun 2006 tentang Standar Isi. Jakarta: Depdiknas.

Depdiknas. (2008). Keputusan Direktur Jenderal Pendidikan Menengah Nomor: 7013/D/KP/2013, Tanggal 4 Desember 2013, tentang Spektrum Keahlian Pendidikan Menengah Kejuruan.

Fernandez, H.J.X. (1984). Testing and Measurement. Jakarta: Depdikbud.

Gunawan Ary, H. (2010). Sosiologi pendidikan. Jakarta: Rineka Cipta.

Hendley P., \& Tanner. (1998). "Pupils' Attitudes towards technology in Kev Stage 3 of the National Curriculum: a study of pupils in South Wales". Journal Research in Science \& Technology Education. Vol.8, No.2, pp. 23-45.

Herrick, Michael J. (10 Januari 2000). Assessment of student achievement and learning. what would Dewey say? A recent interview with John Dewey. Journal of Vocational and Technical Education. Vo. 13, No.2, pp.18-32. Diambil pada tanggal 10 April 2009 dari http://www.yahoo.com. 
Holland, J.L. (1973). Making vocational choice. A theory of careers. Engleoowds: Prentice Hal, Inc.

Hurlock, E.B. (1980). Developmental psychology, a life-span approach (Terjemahan Istiwidayati \& Soedjarwo). New York: McGraw-Hill Inc. (Buku asli diterbitkan 1980).

Isaac, Stephen \& Michael, William B., (1981). Handbook in research and evaluation. California: Edits Publisher.

Isaacson, Lee., E. (1977). Career information in counseling and teaching. Boston: Allyn and Bacon, Inc.

Lembaran Negara Republik Indonesia. (2003). Undang-Undang Republik Indonesia Nomor 20 Tahun 2003 tentang Sistem Pendidikan Nasional. Jakarta: Sekretariat Negara.

London, H.H., (1973). Principles and techniques of vocational guidance. Columbus, Ohio: Charless E. Merrill Publishing Co.

Mifflen, F.J. \& Mifflen, S.C. (1986). Sosiologi Pendidikan. Bandung: Tarsito.

Mohammad Ali, \& Mohammad Asrori. (2009). Psikologi Remaja. Jakarta: PT. Bumi Aksara.

Morris, William. (1982). The American heritage dictionary. Boston: Haughton Mifflin Company.

Paul E. Brauchle. (2002) A study of Supervisor and Employee Perseptions of Work
Attitudes in Information Age Manufacturing Industries. Journal of Vocational Education Research. Vol. 6, pp. 124-139.

Sudji Munadi. (2005). Model orientasi pemilihan bidang keahlian siswa SMP di $D I Y$. Disertasi doktor, tidak diterbitkan, Universitas Negeri Yogyakarta.

Sumitro. (1998). Pengantar ilmu pendidikan. IKIP Yogyakarta: UPP IKIP Yogyakarta.

Super, D.E. (1957). The Psychology of Career. New York: Harper \& Brothers.

Syamsu Yusuf. (2001). Psikologi perkembangan. Bandung: Penerbit PT. Remaja Rosdakarya.

Thompson, J.F. (1973). Foundations of vocational education, Social and philosophical concepts. New Jersey: Prentice Hall.

Tiedeman, D.V., \& O' Hara, R.P. (1963). Career development: Choice and adjustment. Princenton, N.J.: College Entrance Examination Board.

Vroom, Victor H. (1979). Management and motivation. New York: Penguin Book.

Zahrowi Ahmad. (2007). Minat siswa kelas 3 SMP di Kecamatan Piyungan untuk memilih SMK. Tesis Magister, tidak diterbitkan, Universitas Negeri Yogyakarta. 